\title{
The evaluation of industrial cement production plant on the environmental pollution using magnetic susceptibility technique
}

\author{
Hadi Ghorbani ${ }^{1}$, Ali Aghababaei ${ }^{2^{\star}}$, Hamid Reza Mirkarimi ${ }^{3}$ \\ ${ }^{1}$ Department of Soil and Water College of Agriculture, Shahrood University of Technology, Shahrood, Iran \\ ${ }^{2}$ Soil Sciences, Faculty of Agriculture, Shahrood University of Technology, Shahrood, Iran; \\ *Corresponding Author: babaei11.ali@gmail.com \\ ${ }^{3}$ Faculty of Agriculture, Science and Research Branch, Islamic Azad University, Tehran, Iran
}

Received 26 September 2013; revised 25 November 2013; accepted 23 December 2013

Copyright (C) 2013 Hadi Ghorbani et al. This is an open access article distributed under the Creative Commons Attribution License, which permits unrestricted use, distribution, and reproduction in any medium, provided the original work is properly cited.

\section{ABSTRACT}

Different pollutants in soil, water, and other parts of the environment are so important in portraying environmental pollution, and could come from different source of pollutions including industrial activities. Entering metals into the soil by human activities is an important process in the geochemical cycling of heavy metals. Among the potentially toxic metals, mercury, lead, cadmium, nickel, arsenic, selenium and chromium could be named as the most toxic. Each of these elements is used in industrial activities and most of them are considered as by-products of mining, refining and similar industrial activities. Although the establishment of cement factories is usually associated with job creation and other economic aspects, the purpose of economic interests, is inevitable environmental damage caused by cement factories. Therefore, research on pollution originated from factories appears to be necessary. In order to determine the effect of cement production on farmland around Shahrood cement factory, soil samples were taken from surface soils from depth of $0-30 \mathrm{~cm}$. The samples were analyzed using atomic absorption spectrometer instrument after samples preparation using standard frequently used methods. Soil magnetic susceptibility of the samples was also measured using Saskopto meters MFK1-FA. The results showed that among the parameters studied, the element of Zinc has shown the lowest mean value equal to $0.31 \mathrm{mg} \cdot \mathrm{kg}^{-1}$ and iron has shown the highest mean value equal to

\section{$6.36 \mathrm{mg} \cdot \mathrm{kg}^{-1}$.}

Keywords: Magnetic Susceptibility; Soil; Cement; Pollution

\section{INTRODUCTION}

Development of the cement industry is going through a growing process. In this regard, it is unavoidable environmental damage caused by cement factories. Therefore, pollution from factories and industrial activities can be beneficial for the environment. Determination of metals in soil, water, plant and sediment, is so important in portraying of environmental pollution. The transition of metals into the atmosphere by human activities is an important process in the geochemical cycling of heavy metals.

Heavy metals are a source of contamination in soil, water and air, which mainly enter the environment through various activities such as mining, manufacturing. Pollution from cement factories, could be the primary dust, heavy metals in calcareous materials, and clay, and kiln fuels. The effect of mining on the environment is different, such as the quality of the ore, mining methods, land and many others factors. Extraction and processing of mineral resources will have a great influence on soil resources, air, water and biological resources [1].

Given the increasing demand for mineral resources, we have to do protective measures and engineering, through air pollution control, water and soil, which minimized the problems in the area and away from it. Although these conservation measures will increase the cost of the products extraction and preparation, and thus 
increase the price of all items from these materials, instead, future generations will be equally or more efficient. In recent years, scientists have used a method based on magnetic measurements for the assessment and monitoring of soil contamination, and magnetic susceptibility can be used to identify contaminated soil [2].

Today, there is a traditional chemical measurement method for analysis of soil samples. They are used to determine the amount of heavy metal pollution levels and spatial characteristics-Temporal; It is very time consuming and costly [3]. Susceptibility measurements of soil can be considerable method for assessment of heavy metals in soil [4]. Susceptibility might be a good indicator for the assessment of pollution from human activities such as the use of chemical fertilizers and pesticides in agriculture too, traffic, roads, mines, metallurgical and industrial plants [5].

Happon studied the soil around mining and smelting of metals, using Magnetic susceptibility. Currently, waste heap, is the largest industrial waste and smelting facility (Table 1). This study concluded that the concentrations of metals such as iron, arsenic, manganese, chromium, lead and mercury, are at high levels in the soil [6].

Durza and colleagues (1993) showed that there is a correlation between the amount of heavy metals in soils and their magnetic susceptibility. Study of soils around metallurgical plants, has demonstrated that although the show is a high correlation between magnetic susceptibility elements such as iron, metals such as nickel and cobalt, they also show a significant magnetic susceptibility. In other similar studies, magnetic susceptibility soil samples near the pile of junk, is the special difference with further samples. The maximum value of magnetic susceptibility, has been reported in the waste pile (where there is the greatest pollutant metals) [7].

Hay et al., (1997), studied the shallow soil of England using magnetic susceptibility method. This study concluded that soil pollution is higher, in near the main road, which corresponded with susceptibility criteria. Also, these routes are more polluted compared to the parks [8].

Asubiojo et al. (1991) studied the effect of cement production, on the elemental composition of the soil around two cement factories in Nigeria. They measured the concentrations of 21 elements in 30 soil samples. They concluded that calcium, phosphorus, sulfur, chromium, nickel, copper and zinc are rich in soil samples (assuming the cement factory). They also found that the element of cement (calcium) had a good correlation with magnesium, sulfur, iron, nickel and copper in the soils studied, and it had been inversely proportional to the concentrations of silica and titanium [9].

Fukuzaki et al. (1986) reported that the adsorption of mercury emissions from cement factories is carried into
Table 1. Magnetic susceptibility of some common chemical elements in the soil [11].

\begin{tabular}{cc}
\hline Element name & $\begin{array}{c}\text { Unit mass Magnetic susceptibility } \\
\left(10^{-6} \text { c.g.s. units }\right)\end{array}$ \\
\hline $\mathrm{Cu}$ & $-5 / 46$ \\
$\mathrm{~B}$ & $-6 / 7$ \\
$\mathrm{Zn}$ & $-11 / 4$ \\
$\mathrm{~S}$ & $-15 / 5$ \\
$\mathrm{Cd}$ & $-19 / 8$ \\
$\mathrm{~Pb}$ & -23 \\
$\mathrm{Hg}$ & $-24 / 1$ \\
$\mathrm{Se}$ & -25 \\
$\mathrm{P}$ & $-26 / 6$ \\
$\mathrm{Mo}$ & $-96 / 5$ \\
$\mathrm{Ca}$ & +40 \\
$\mathrm{Cr}$ & +180 \\
$\mathrm{Mn}$ & +529 \\
$\mathrm{Ni}$ & Ferro \\
$\mathrm{K}$ & $+20 / 8$ \\
$\mathrm{Na}$ & +16 \\
\hline
\end{tabular}

the atmosphere by plant leaves and humus derived from the leaves [10].

Ighbal et al. (2001), by studying the effects of the pollution caused by cement dust, on the growth of some plant species in Pakistan, concluded a significant reduction in vegetation cover, leaf number and height of plants due to the cement pollutants [11].

Significant correlation between magnetic properties and heavy metal concentrations in soils was observed in numerous studies (Dearing et al. 2001; Jordanova et al., 2003; Lu \& Bai, 2006). Strzyszcz \& Magiera (1998) reported a positive correlation between magnetic susceptibility and concentration of $\mathrm{Zn}, \mathrm{Pb}$ and $\mathrm{Cd}$ in Polish topsoils [12-15]. Schmidt et al. (2005) observed a strong correlation between magnetic susceptibility and heavy metal in a former industrial iron production and processing site near Bradford, England [16]. Strong correlations have also been found between magnetic susceptibility and the concentration of $\mathrm{Pb}, \mathrm{Cd}, \mathrm{Cu}$ and $\mathrm{Zn}$ in urban soils in Hangzhou city, China [17].

The main objectives of the present research were the identification of heavy metals in agricultural soils of the study area, identifying critical areas (if any) to heavy metal contamination, mapping the data from the magnetic susceptibility and chemical analysis methods and studying the relationship between these two methods. 


\section{MATERIALS AND METHODS}

\subsection{Site Description}

Shahrood cement factory is situated in $36^{\circ} 28^{\prime} 45.08^{\prime \prime}$ North and $54^{\circ} 54^{\prime} 1.76^{\prime \prime}$ East. The factory is located in the northwest of the city of Shahrood, and at $15 \mathrm{~km}$ from the east of Mojen. In this area, the predominant wind direction is from the northwest to the southeast and east, sometimes, the wind is north to south. Air flow is such that the pollution leads further to the west. Based on the regional topography, it was observed that pollutants flows from the south-western to the south.

\subsection{Soil Sampling}

In order to determine the effect of cement on farmland around Shahrood, soil samples were collected from the agricultural land surfaces from a depth of $0-30 \mathrm{~cm}$. Soil sampling were done in June 2009 (Figure 1). Taken samples were collected in standard plastic bags and moved to the Shahrood University of Technology, in order to perform other laboratory procedures (Figure 2).

\subsection{Soil Samples Preparation}

Soil samples were dried at $105^{\circ} \mathrm{C}$ for 24 hours, and then were grounded and screened with $2 \mathrm{~mm}$ sieve. Sieved samples were weighed to $2 \mathrm{~g}$, and they were placed at $350^{\circ} \mathrm{C}$ for half an hour, and finally got reflux with $25 \mathrm{ml}$ of $25 \%$ nitric acid for 15 minutes. The extract was filtered with Whatman filter paper 42 , and then it was diluted with a solution of nitric acid [18].

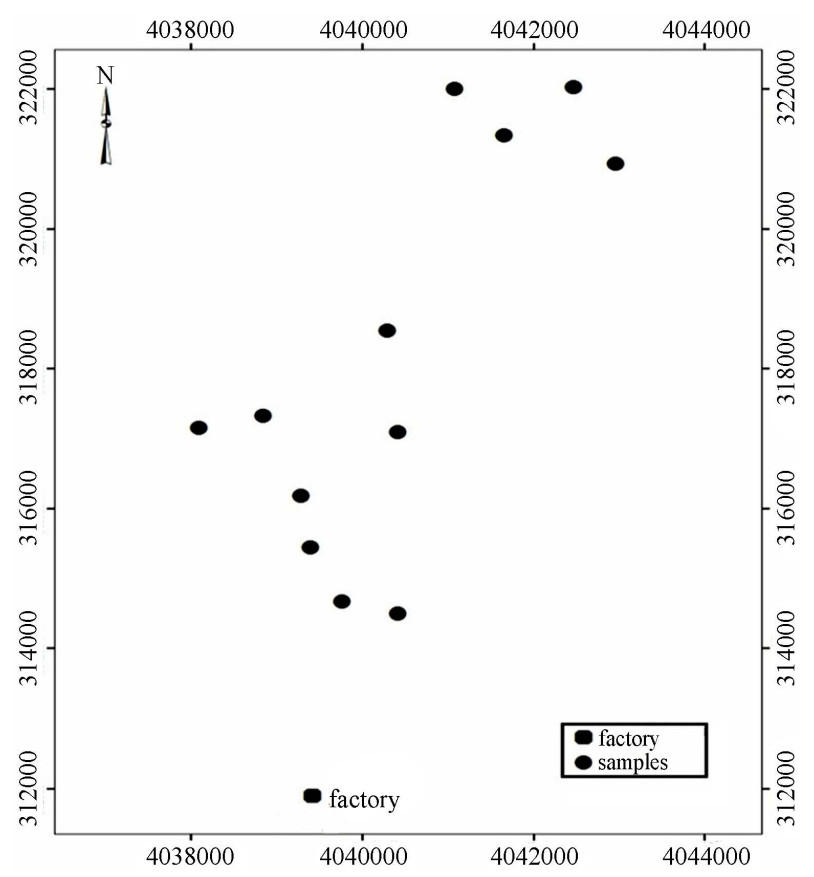

Figure 1. Position of sampling points in the study area.

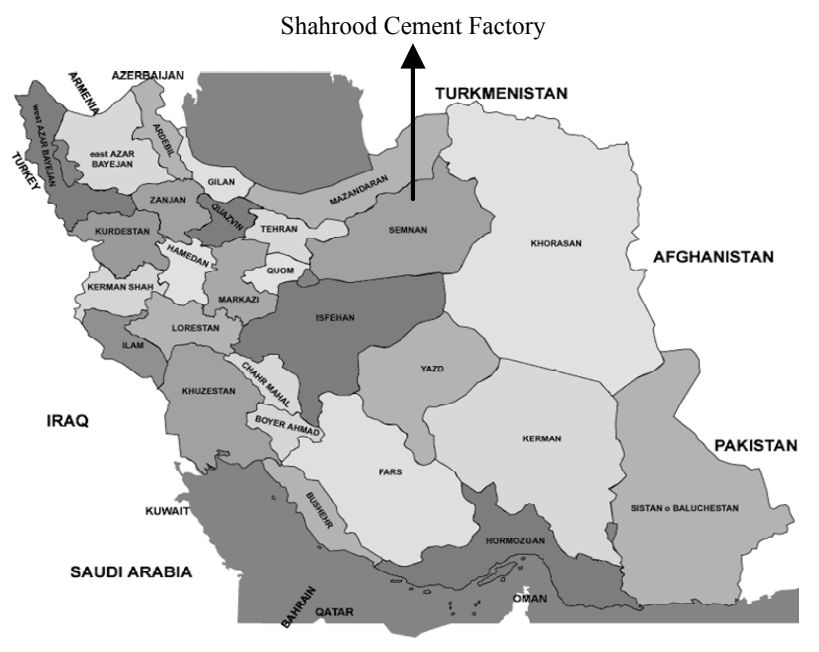

Figure 2. Map of the study area.

\subsection{Soil Analysis}

\subsubsection{Atomic Absorption Spectrometry}

Soil samples were analyzed by atomic absorption spectrometer models Shimadzo AA-670. The calibration curve was fitted to each metal. The standard solutions and samples were prepared using standard frequently used methods.

\subsubsection{Magnetic Susceptibility Technique}

Magnetic susceptibility might be a good index of pollution from human activities, such as overdose of chemical fertilizers and pesticides in agriculture, road traffic, factories, mines and metallurgical industries [5]. To measure the magnetic susceptibility of the samples, they were passed through a $2 \mathrm{~mm}$ sieve and 20 grams of each soil the samples were taken for magnetic susceptibility readings. The samples were inserted inside the machine chamber and the corresponding readings were made based on the micro using the instrument model MFK1FA.

\subsection{Maps Preparation}

In order to evaluate and describe the situation in a better way, the results were analyzed using Arc GIS9.3 software, and the maps were prepared.

\subsection{Statistical Analysis}

The data were also analyzed using SPSS 14.0 statistical software and some statistical parameters as well as the descriptive data were discussed.

\section{RESULTS AND DISCUSSIONS}

\subsection{Description of Variables}

Statistical analysis of the data has been determined, in 
the form of tables and diagrams. In this analysis, it used six elements, such as $\mathrm{Cu}, \mathrm{Cd}, \mathrm{Pb}, \mathrm{Zn}, \mathrm{Mn}$ and $\mathrm{Fe}$; Figure 3 shows the mean values of heavy metals concentrations in soils.

Among the parameters studied, the element has the lowest mean value, which is equal to $0.31 \mathrm{mg}$, and $\mathrm{Fe}$ has a maximum mean value, which is equal to 6.36 $\mathrm{mg} \cdot \mathrm{kg}^{-1}$ (Table 2).

The maximum susceptibility is related to iron, which is equal to $9.84 \mathrm{mg} \cdot \mathrm{kg}^{-1}$. The lowest measured value corresponds to the element of $\mathrm{Cd}$, which is equal to 0.13 $\mathrm{mg} \cdot \mathrm{kg}^{-1}$.

The most significant difference is related to the iron, and the minimum range is related to the $\mathrm{Zn}$. The element of $\mathrm{Zn}$ has the lowest standard deviation, and maximum deviation is related to iron. Measured metal concentrations observed in this study were much lower than rates in other similar studies, and it is still lower than the international standard of WHO. The iron was received attention since it is an essential element of the earth's crust, and its high concentration relative to the other elements.

Map concentrations of elements such as iron, zinc, manganese, copper, cadmium and lead are shown in Figure 4.

Map concentrations of magnetic susceptibility are also shown in Figure 5.

\subsection{Correlation between the Elements}

Comparison of the correlation matrix is the simplest way to compare the frequency distribution of symbols. The results show the relationship between the parameters of the study (Table 3). This table shows that there is a highly significant correlation between $\mathrm{Cd}$ and $\mathrm{Pb}$ elements. Source of cadmium, which is caused by fertilizers and pesticides or chemical industry, as well as the source of lead poisoning can be caused by traffic, industrial activities and similar sources.

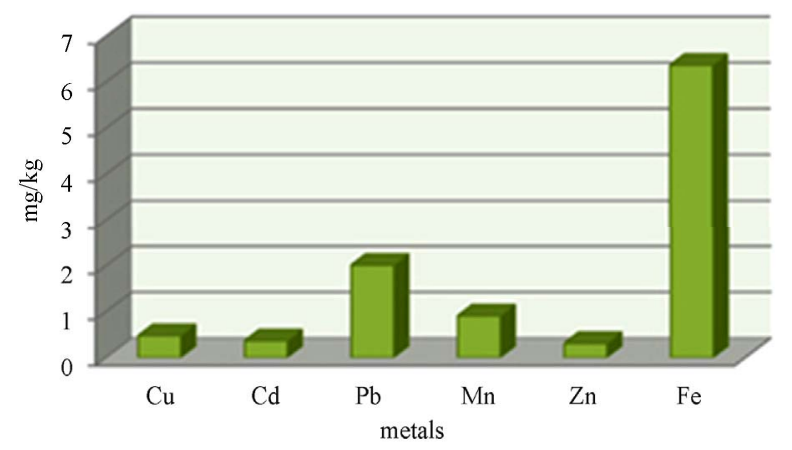

Figure 3. Mean values of metals concentration in soils.

Table 2. Values and other statistics of the mean metals concentration in soil.

\begin{tabular}{ccccccccccc}
\hline Elements & Average & Median & Mode & $\begin{array}{c}\text { Standard } \\
\text { devision }\end{array}$ & Skewness & Elongation & $\begin{array}{c}\text { Cofficient of } \\
\text { Variation }\end{array}$ & Min & Max \\
\hline Cu & 0.4781 & 0.3500 & 0.35 & 0.48322 & 3.412 & 11.737 & 1.73 & .28 & 2.00 \\
Cd & 0.3650 & 0.2700 & 0.28 & 0.33584 & 2.825 & 8.705 & 1.24 & .13 & 1.37 \\
Pb & 2.0100 & 1.8550 & 1.14 & 0.75641 & 0.764 & -0.76 & 2.43 & 1.14 & 3.57 \\
Mn & 0.90850 & 0.89100 & 0.677 & 0.124970 & 0.084 & -0.039 & 0.438 & 0.677 & 1.113 \\
Zn & 0.31100 & 0.29850 & 0.282 & 0.041641 & 0.448 & -1.098 & 0.129 & 0.255 & 0.384 \\
Fe & 6.3658 & 6.0450 & 4.91 & 1.48442 & 1.495 & 1.806 & 4.93 & 4.91 & 9.84 \\
Magnetic susceptibility & 0.000501875 & 0.000516050 & 0.0005629 & 0.0001138452 & -234 & -0.690 & 0.0003740 & 0.00030720 .0006812 \\
\hline
\end{tabular}

Table 3. Relationships between the studied metals.

\begin{tabular}{|c|c|c|c|c|c|c|c|}
\hline & $\mathbf{C u}$ & Cd & $\mathbf{P b}$ & Mn & Zn & $\mathbf{F e}$ & Magnetic susceptibility \\
\hline $\mathbf{C u}$ & 1 & & & & & & \\
\hline $\mathbf{P b}$ & 0.302 & $0.766^{* *}$ & 1 & & & & \\
\hline Mn & 0.365 & -0.566 & -0.469 & 1 & & & \\
\hline Zn & $0.601^{*}$ & -0.322 & -0.055 & 0.461 & 1 & & \\
\hline $\mathbf{F e}$ & 0.123 & -0.159 & 0.335 & 0.204 & 0.18 & 1 & \\
\hline Magnetic susceptibility & 0.498 & 0.204 & -0.079 & 0.173 & 0.285 & $-0.671^{*}$ & 1 \\
\hline
\end{tabular}

${ }^{*}$ Correlation is significant at $5 \% ;{ }^{* *}$ Correlation is significant at $1 \%$ level. 

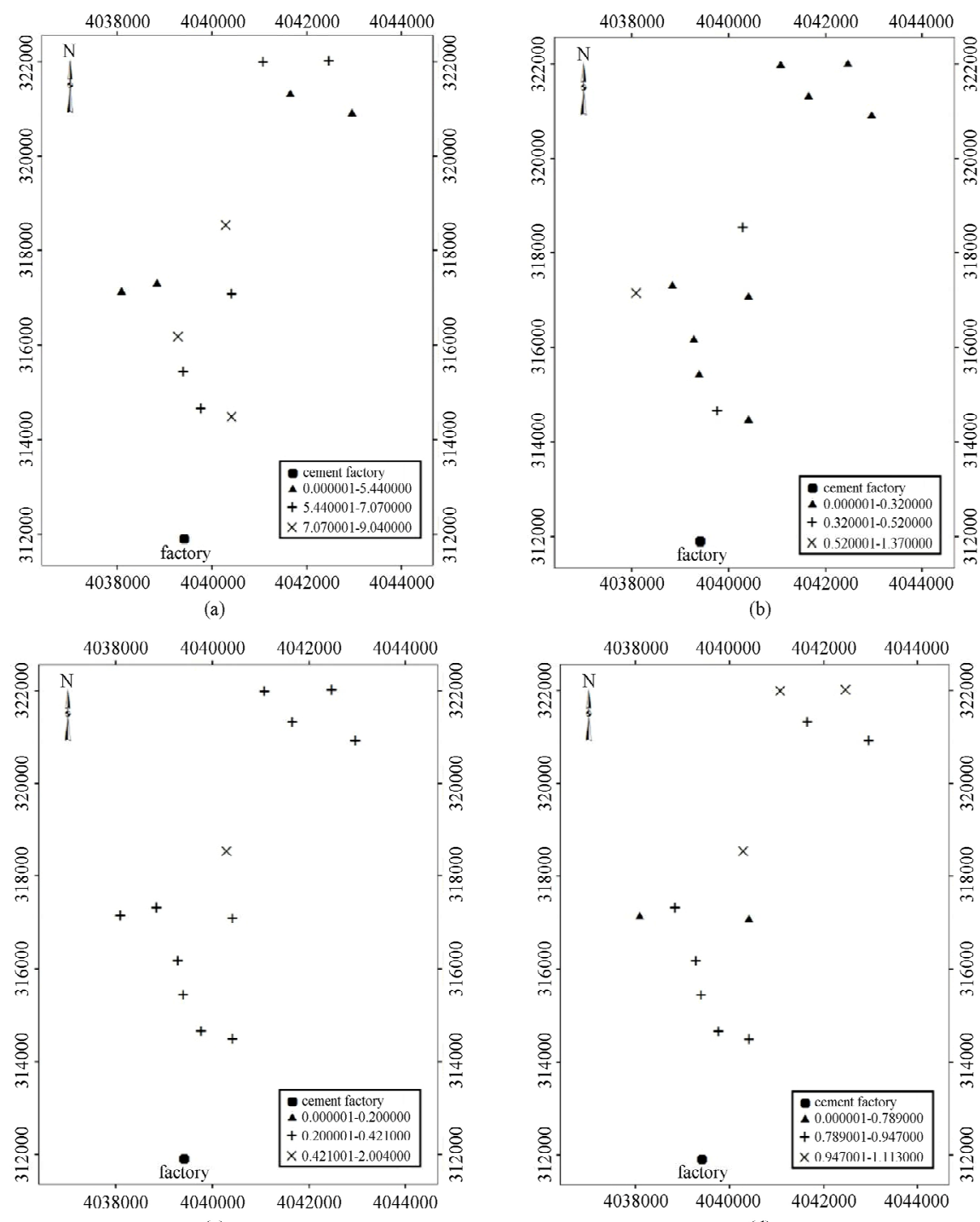

(b)
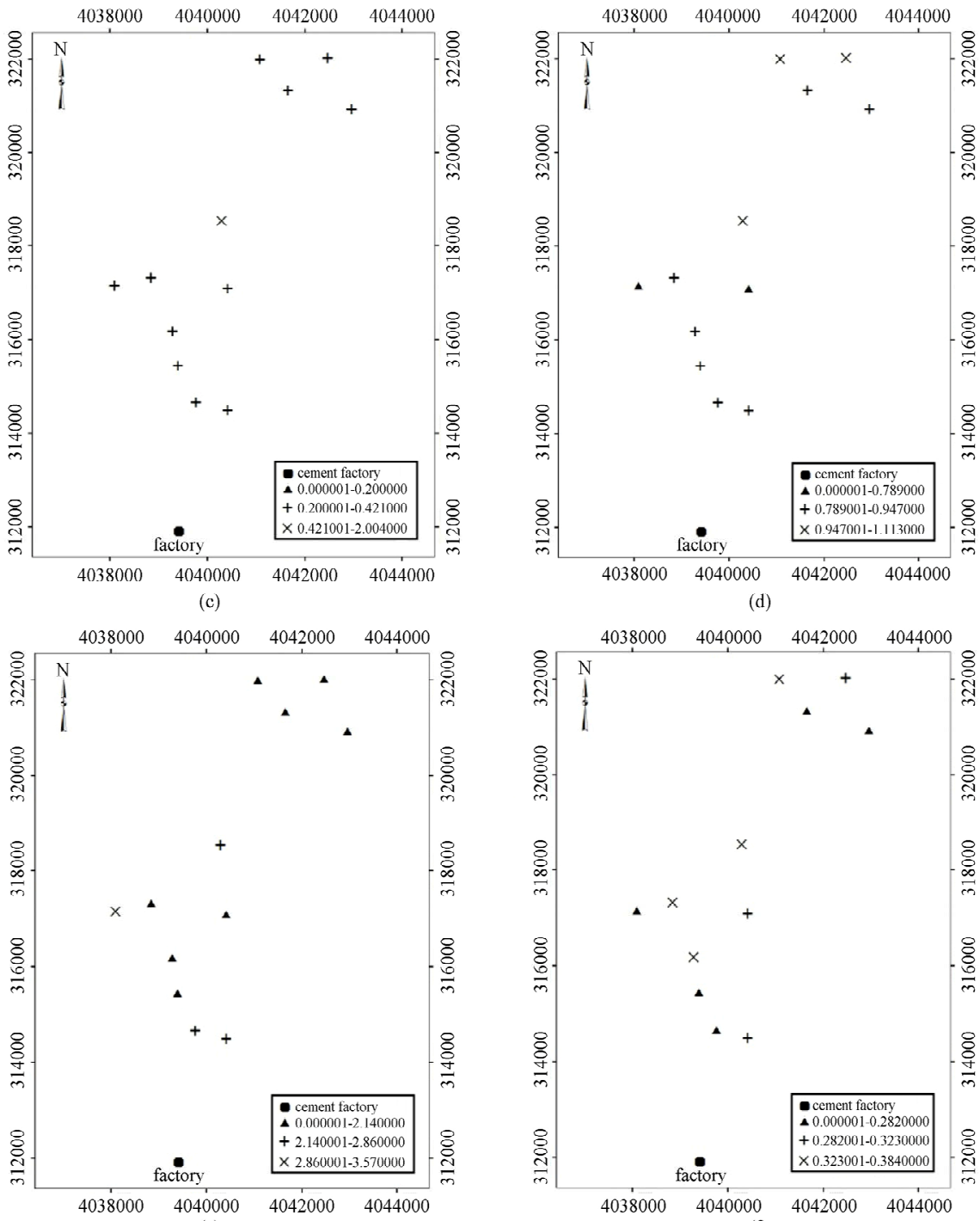

$$
\text { (e) }
$$

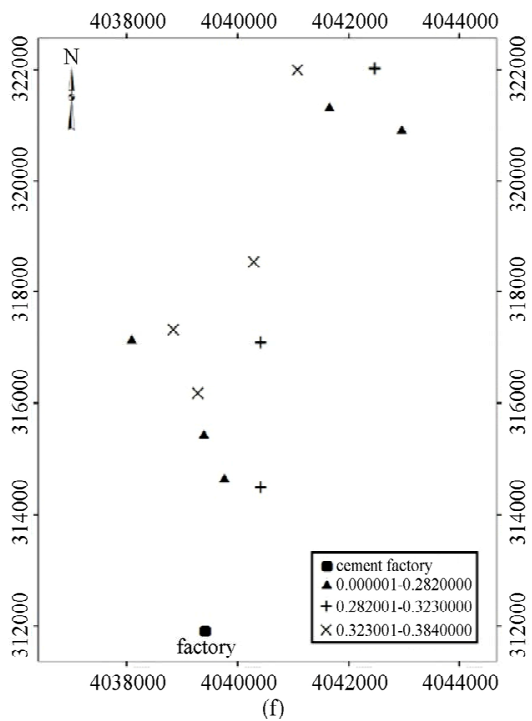

Figure 4. View of the elements concentration in soil (ppm). (a) $\mathrm{Fe}$; (b) $\mathrm{Cd}$; (c) $\mathrm{Cu}$; (d) $\mathrm{Mn}$; (e) $\mathrm{Pb}$; (f) $\mathrm{Zn}$. 


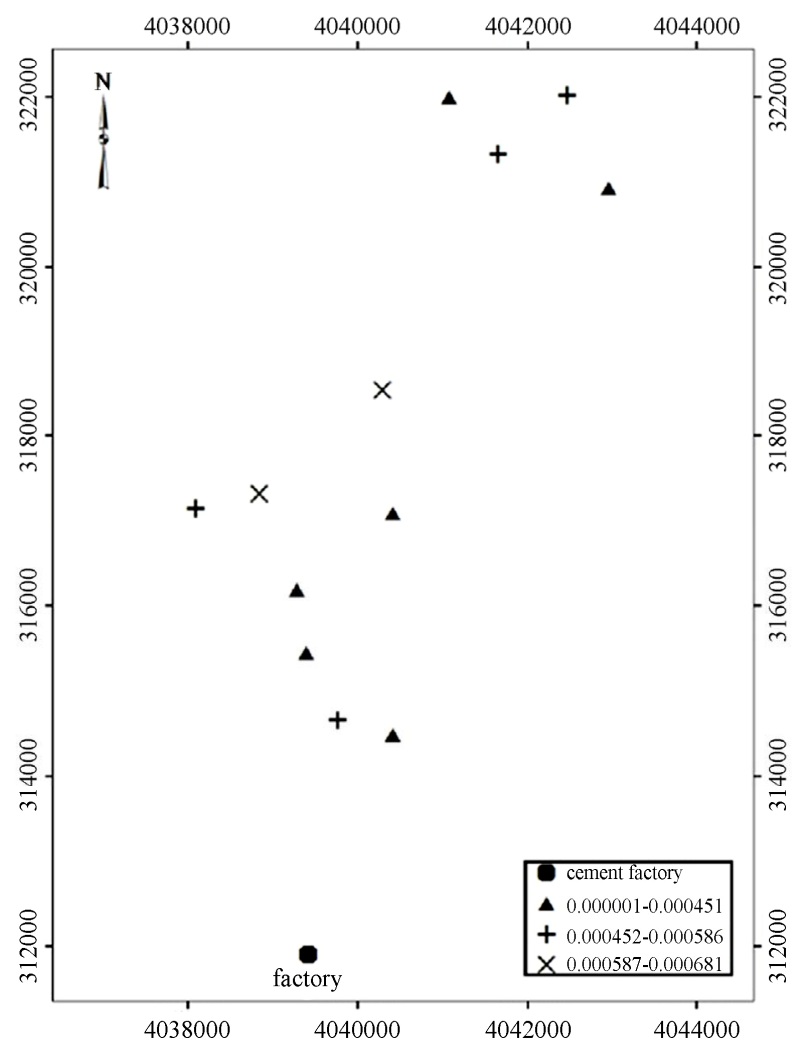

Figure 5. View of the magnetic susceptibility concentration in soil $\left(\mathrm{mg} \cdot \mathrm{kg}^{-1}\right)$.

There was a significant correlation between $\mathrm{Cu}$ and $\mathrm{Zn}$. The particles may be due to industrial activities or fertilizers. It is the important point that there was a significant negative correlation between iron and magnetic susceptibility (Table 4).

The analysis of variance also showed the changes between metals and soil samples. There were significant differences for some metals; for example, for the element of lead, iron and also for magnetic susceptibility.

The sampling area around the cement factory was divided in to three sub-areas. The results showed that some elements such as iron had the lowest concentration in the soil at the third levels which was the farthest distance from the cement factory. It was also so similar for lead (Figure 6). For other elements such as $\mathrm{Cu}, \mathrm{Cd}, \mathrm{Pb}$ and $\mathrm{Zn}$ the second level area showed greater values than the first (the closest to the factory) and the third (the farthest from the factory) levels. However, it could be due to the wind direction which may help the cement dust to different direction and distance.

Magiera et al. (2006) and Hoffmann et al. (1999) found in their study that Generally, the amount of settled magnetic particles and heavy metals in the topsoils decreases with increasing distance far from the emission source; That it corresponded with the results of this research $[19,20]$.
Table 4. Statistical analysis of the elements and soil samples.

\begin{tabular}{cccc}
\hline Element & df & MS & F \\
\hline Cu & 2 & 0.221 & $0.935^{\text {ns }}$ \\
Cd & 2 & 0.099 & $0.856^{\text {ns }}$ \\
Pb & 2 & 1.635 & $4.867^{*}$ \\
Mn & 2 & 0.017 & $1.071^{\text {ns }}$ \\
Zn & 2 & 0.002 & $0.971^{\text {ns }}$ \\
Fe & 2 & 6.004 & $4.418^{*}$ \\
Magnetic susceptibility & 2 & $4.02409525 \mathrm{e}-008$ & $5.881^{*}$ \\
\hline
\end{tabular}

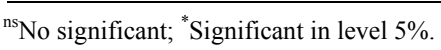

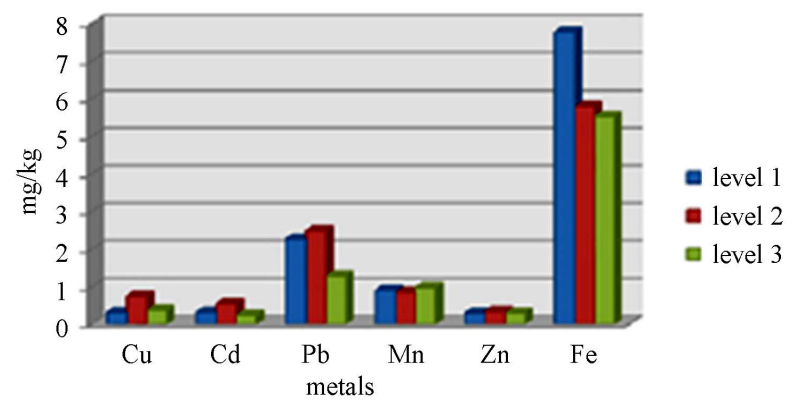

Figure 6. Mean metal concentration values in different distance.

Figure 7 has shown the magnetic susceptibility values at different distance from the cement factory. The results showed higher magnetic susceptibility values at the level 2 compared to the levels 1 and 3 in terms of distance from the factory.

The results obtained in this research were similar, with some studies worldwide. In one of the regions of Italy, the concentrations of heavy metals were analyzed and it was shown that the amount of lead, cobalt and copper exceeded the law in Italy that is the standard used by residents for residents, and soil nutrients. In fact, concentrations of copper, cobalt and lead in soils measured in the Valley Agri, respectively 34, 25 and $179 \mathrm{mg} / \mathrm{kg}$;

While Italians extent permitted by law, for the concentration of heavy metals in these elements are, respectively, 120,20 and $100 \mathrm{mg} / \mathrm{kg}$.

The researchers attributed the high levels of lead and cobalt, the road traffic in the study area. While the concentrations of copper, are related the use of copper acetate in vineyards. They identified two groups of metals in the soil, the first group metals such as iron, nickel and magnesium that these metals are dependent on the natural properties of soil.

The second group is metals such as copper lead and zinc, that they are related to human activities. Statistical analysis was performed and showed that soil magnetic susceptibility is related to the elements of the second group [21]. 


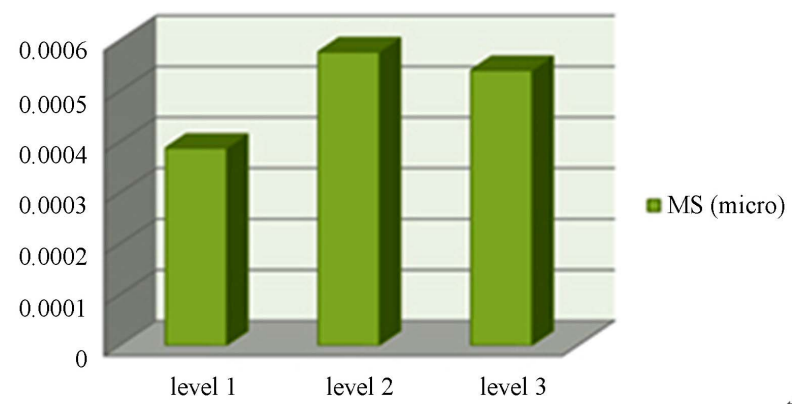

Figure 7. Magnetic susceptibility values at different distances from the factory.

Alkhasman and Shawabkeh (2005), the assessment and studied the distribution of heavy metals in soils around the cement factory in southern Jordan. The researchers compared the soil around the factory with metals in urban soils. This test was selected to 30 samples of soil from the surrounding area Gadissia cement factory in southern Jordan.

Metals were tested, such as lead, zinc, cadmium, iron, copper and cream in a soil survey area. High concentrations of lead, zinc and cadmium in soil samples evaluated, were associated with human activities such as cement plants and agricultural activities. In their study, the results found that the concentrations of lead, zinc and cadmium were highest levels depending cement factory; While chromium concentration was low, and they showed that all metals are concentrated on the soil surface, and the lower part of the soil is reduced. Mobility due to the reflection of the physical properties of the soil is alkaline PH value. In this study, high concentrations of metals were observed around the cement factory. Particles showed that the highest concentrations are found around the cement factory. High levels were also found in the East and North factory. There was a highly significant correlation between metals in all samples, including lead, zinc, cadmium, copper and chromium. High iron levels observed in the study area in the northern part of the cement factory, While the lowest values in the upper part of the soil [17].

\section{CONCLUSIONS}

Metal distributions in the study area indicate that, although metal concentrations are low, they are affected by human activities, including agricultural activities as well as cement factory. The distribution of metal concentrations in the area was an indicator of the files in the history of the region's impure. Magnetic susceptibility values indicate that it is an appropriate method to assess soil contamination.

In general, it is likely to have lower levels of pollutants resulting from human activities in the studied area. However, cadmium could be accumulated in the soil due to application of chemical fertilizers especially phosphorous fertilizers as well as industrial cement production plant.

\section{REFERENCES}

[1] Salari, M. and Abbasi, C. (2006) Environmental pollution cement plants. Mining Student 5th Conference, Isfahan, 11-20 November 2006, 702.

[2] Botkin, D.B., Keller, E.A. and Rosenthal, D.B. (1995) Environmental science: Earth as a living planet. Wiley, New York.

[3] Sterckeman, T., Douay, F., Proix, N. and Fourrier, H. (2000) Vertical distribution of $\mathrm{Cd}, \mathrm{Pb}$ and $\mathrm{Zn}$ in soils near smelters in the North of France. Environmental Pollution, 107, 377-389.

http://dx.doi.org/10.1016/S0269-7491(99)00165-7

[4] Heller, F., Strzyszcz, Z. and Magiera, T. (1998) Magnetic record of industrial pollution in forest soils of Upper Silesia, Poland. Journal of Geophysical Research, 103, 17767 17774. http://dx.doi.org/10.1029/98JB01667

[5] Coppola, R., Caggiano, R., D’Emilio, M. and Ragosta, M. (2005) Comparison between in situ soil magnetic susceptibility measurements and heavy metal concentration. Geophysical Research Abstracts, 7, Article ID: 09077.

[6] Hoppan, J. and Balgav, P.V. (1992) Dv retised heapmaterial revaluatmn. APSECOS Iso"sice, 12. (in Slovak).

[7] Durza, O., Gregor, T. and Antalova, S. (1993) The effect of the heavy metals soil contamination on magnetic susceptibility. Acta Universitatis Carolinae, Geologica, 37, 135-143.

[8] Hay, K.L., Dearing, J.A. and Baban, S.M.J. (1996) A preliminary attempt to identify pollution particulates in English topsoil, using magnetic susceptibility. Annales Geophysicae, Part I, 145.

[9] Asubiojo, O.I., Aina, P.O. and Oluwole, A.F. (1991) Effect of cement production on the elemental composition of soils in the neighborhood of two cement factories. Water, Air, and Soil Pollution, 57, 819-828.

[10] Fukuzaki, N., Tamura, R., Hirano, Y. and Mizushima, Y. (1986) Mercury emission from a cement factory and its influence on the environment. Atmospheric Environment, 20, 2291-2299. http://dx.doi.org/10.1016/0004-6981(86)90059-4

[11] Iqbal, M.Z. and Shafug, M. (2001) Periodical effect of cement dust pollution on the growth of some plant species. Turkish Journal of Botany, 25, 19-24.

[12] Dearing, J.A., Hannam, J.A., Anderson, A.S. and Wellington, E.M.H. (2001) Magnetic, geochemical and DNA properties of highlymagnetic soils in England. Geophysical Journal International, 144, 183-196. http://dx.doi.org/10.1046/j.0956-540X.2000.01312.x

[13] Jordanova, N.V., Jordanova, D.V., Veneva, L., Yorova, K. and Petrovský, E. (2003) Magnetic response of soils and vegetation to heavy metal pollution-A case study. Environmental Science \& Technology, 37, 4417-4424. http://dx.doi.org/10.1021/es0200645 
[14] Lu, S.G. and Bai, S.Q. (2006) Study on the correlation of magnetic properties and heavy metals content in urban soils of Hangzhou City, China. Journal of Applied Geophysics, 60, 1-12.

http://dx.doi.org/10.1016/j.jappgeo.2005.11.002

[15] Strzyszcz, Z. and Magiera, T. (1998) Magnetic susceptibility and heavy metals contamination in soils of southern Poland. Physics and Chemistry of the Earth, 23, 11271131. http://dx.doi.org/10.1016/S0079-1946(98)00140-2

[16] Schmidt, A., Yarnold, R., Hill, M. and Ashmore, M. (2005) Magnetic susceptibility as proxy for heavy metal pollution: A site study. Journal of Geochemical Exploration, 85, 109-117. http://dx.doi.org/10.1016/j.gexplo.2004.12.001

[17] Al-Khashman, O.A. and Shawabkeh, R.A. (2005) Metals distribution in soils around the cement factory in southern Jordan. Environmental Pollution, 140, 387-394.
[18] Mulay, L.N., Weissberger, A. and Rossiter, B.W. (1972) Physical methods of chemistry. Interscience, New York.

[19] Hoffmann, V., Knab, M. and Appel, E. (1999) Magnetic susceptibility mapping of roadside pollution. Journal of Geochemical Exploration, 66, 313-326. http://dx.doi.org/10.1016/S0375-6742(99)00014-X

[20] Magiera, T., Strzyszcz, Z., Kapička, A., Petrovský, E. and Magprox Team (2006) Discrimination of lithogenic and anthropogenic influences on topsoil magnetic susceptibility in Central Europe. Geoderma, 130, 299-311. http://dx.doi.org/10.1016/j.geoderma.2005.02.002

[21] Caggiano, R., Coppola, R., D’Emilio, M., Di Leo, S., Macchiato, M. and Ragosta, M. (2005) Comparison between in situ soil magnetic susceptibility measurements and heavy metals concentration: The case study of the agri valley, Basilicata Italy. Geophysical Research Abstracts, 7, Article ID: 09077. 